\title{
THE EFFECT OF PROGRESSIVE MUSCLE RELAXATION TO MENTAL HEALTH ON ADOLESCENT
}

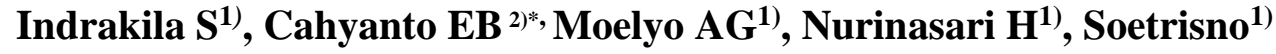 \\ ${ }^{1)}$ Medical Faculty, Univeritas Sebelas Maret, Ir. Sutami Street 36 A, Kentingan Surakarta 57126, Indonesia \\ ${ }^{2}$ Associate Degree of Midwifery Department, Vocational School, Universitas Sebelas Maret Jl. Kolonel \\ Sutarto 150 K Jebres Surakarta 57126, Indonesia \\ * Corresponding author \\ E-mail: erindrabudi@staff.uns.ac.id
}

\begin{abstract}
Background: During the covid-19 pandemic, there are changes in living habits that must be faced by everyone, including teenagers. Adolescents in orphanages in adjustment experience stress, depression and sleep disturbances that can affect the quality of life. For this reason, progressive muscle relaxation efforts can be used as a way to improve adolescent mental health.

Methods: This type of research is an analitic observational. This research was conducted at the Marhdatillah Sukoharjo Orphanage, Central Java. The subjects in this study were 42 people living in the Mardhatillah orphanage which divided into control group (27 people) and intervention group (15 people). In both the control group and the intervention group, mental health assessments were carried out twice. In the intervention group, prior to the second mental health assessment, a progressive muscle relaxation intervention was performed. Data was collected using the Strengths and Difficulties Questionnaire (SDQ) and intervention. Analyzed by independent t-test with SPSS 21.

Results: The results of the independent $t$ test were significant $(\mathrm{p}=0.042)$. The control group consisted of 27 subjects with a mean post-test SDQ score of 23.8 (abnormal) and post-test 13.22 (borderline). The intervention group consisted of 15 subjects with a mean SDQ score of 22.2 pre-test (abnormal) and 9.40 post-test (normal).

Conclusion: Progressive muscle relaxation can improve mental health in adolescents who live in the Mardhatillah orphanage, Sukoharjo, Central Java.
\end{abstract}

Keywords: muscle relaxation, mental health, teenagers, orphanage

\section{INTRODUCTION}

Currently the world is facing a pandemic due to the corona virus disease 2019 (COVID 19) caused by the Severe Acute Respiratory Syndrome Coronavirus 2 (SARS-CoV-2). Based on official data released by the Indonesian government in
2021 through the website, the number of confirmed cases in 222 countries as of January 7, 2021, reached 85,929,428 patients, 1,876,100 died. In Indonesia, the number of sufferers reached 797,723, recovered 659,437 people, and 23,520 who died. Governments in various 
countries including Indonesia have implemented health protocols to prevent and control the transmission of COVID 19 including: washing hands using soap with running water or alcohol-based antiseptic, maintaining a minimum distance of one meter from other people, using masks that cover the mouth, limit the mobility from one to another ${ }^{[1]}$.

A survey of the impact of health protocols among adolescents in Poland showed that university students experienced high levels of stress and anxiety during the pandemic ${ }^{[2] .}$ Teenagers in the United States who are synonymous with various kinds of activities experience activity restrictions. This has an impact on adolescent mental health by increasing depression and anxiety scores above the normal threshold ${ }^{[3] .}$ A survey of students in China showed that the pandemic had an impact on changing sleep quality ${ }^{[4]}$. Under normal conditions, many teenagers need support to get through the transition period, especially for teenagers who don't live with their families, for example in orphanages, so they are a vulnerable group. In a pandemic, stressors are even greater.

Systematic reviews and metaanalysis of eight databases to determine the impact of COVID 19 on children and adolescents (aged <18 years) found anxiety and depression disorders, emotional reactions and mental health, psychological stress and behavioral disorders that all affect life. For this reason, action is needed to improve mental health conditions among adolescents [5]. The impact of the pandemic also causes sleep disturbances, nightmares in children and adolescents ${ }^{[6]}$.

Adolescence is a transition from childhood to adulthood. Various changes have an impact both physically and psychologically. Under normal conditions, many teenagers need support to get through the transition period, especially for teenagers who don't live with their families, for example in orphanages care to include vulnerable groups. In a pandemic, stressors are even greater ${ }^{[7]}$. The problems of adolescents in the orphanage include aspects of adjustment to the environment in the orphanage such as adjustment to friends at the orphanage, with caregivers, problems adjusting to the surrounding environment, as well as problems adjusting to the school environment ${ }^{[8]}$.

Given the various data above, there is a need for research to determine effective non-pharmacological relaxation methods to maintain the mental health of adolescents, especially those living in orphanages during the COVID-19 pandemic.

This study aims to determine the effect of progressive muscle relaxation (ROP) on the mental health of adolescents living in orphanages during the COVID19 pandemic.

\section{METHODS}

\section{Study Design}

The design that will be used in this study is an experimental pre test and post test with controlled group design.

\section{Sample and Population}

The population in this study were all children who were in the Mardhatillah orphanage, totaling 42 children. Subjects were divided into two groups. The determination of the group by random cluster resulted in 21 people being included in the control group and 21 people being included in the treatment group. However, 6 people did not agree to follow the treatment. So that there are 27 control groups and 15 treatment groups. The treatment group received the intervention of progressive muscle relaxation therapy three times a week for four weeks, the control group received general support as daily. To maintain the fairness aspect, the control group was also given progressive muscle relaxation technique training after the intervention was completed 


\section{Study Variable and Operational Definition}

The variables in this study were progressive muscle relaxation and mental health in adolescents.

Progressive muscle relaxation is a relaxation technique by tensing and then relaxing while doing deep breaths on the muscles of the face to the feet, eyes and forehead, cheeks, mouth, nape, shoulders, hands, chest, stomach, back, buttocks, feet, soles of the feet, while focusing on the feelings at hand. There is an interaction between physical and emotional relaxation thereby reducing psychological stress.

Adolescent mental health is a condition experienced by a teenager which is assessed from the emotional aspect (emotional problems) and behavioral aspects, including pro-social, conduct problems, hyperactivity and relationship problems with peers.

Measurement of adolescent mental health using SDQ. The measurement results by adding up the total score will be categorized into normal, borderline, abnormal. SDQ interpretation is normal 015 , borderline $16-19$, or abnormal $20-40^{[9]}$.

\section{Research Instrument}

The instrument used in this research is a questionnaire. A questionnaire was used to measure mental health which was standardized, namely the Strengths and Difficulties Questionnaire (SDQ). Consisting of 20 question items divided into 5 parts of emotional symptoms, behavioral problems, hyperactivity / inattention, peer relationship problems, prosocial behavior. The SDQ questionnaire is used as an early detection tool for mental health disorders that is valid and reliable, easy and fast, but not as a diagnostic tool ${ }^{[11,12]}$. In this study, the researcher used the total SDQ score with the interpretation: normal 0-15, borderline (above the cut-off) 16-19, abnormal 2040.

\section{Data Analysis}

Normality test is used to see the distribution of groups or variables whether the data is normally distributed or not. The data are in the form of pre-test and posttest results.

To test the difference in mean between the two groups, namely the control group and the intervention group, an independent $t$ test was used as measured by SPSS 21 .

\section{Ethical Clearance}

This study pays attention to research ethics and has applied for an ethical permit from the Ethics Committee of the Faculty of Medicine UNS with an ethical eligibility number

26/UN27.06.0.1/KEP/EC/2021

\section{RESULT}

1. Respondent Characteristics

Characteristics of research subjects are described in the following table:

Table 1.1 Characteristics of respondent

\begin{tabular}{lcc}
\hline Characteristics & n & \% \\
\hline Gender & & \\
Male & 26 & 62 \\
Female & 16 & 38 \\
Mother Education & & \\
Junior High School & 15 & 35.7 \\
Senior High School & 27 & 64.3 \\
\hline
\end{tabular}

The characteristics of the subjects in general are relatively within the same criteria, as presented in table 1.1 the number of subjects is 42 teenagers who live in the Mardhatillah orphanage. Male sex as many as 26 subjects (62\%), more than female adolescents with 16 subjects $(38 \%)$. There are only two levels of education for adolescents living in the Mardhatillah orphanage, which are junior high school with 15 subjects $(35.7 \%)$ and high school with 27 subjects $(64.3 \%)$. 
The characteristics of the age of the subjects in this study are described in the following table:

Table 1.2 The Characteristics of Respondent's age

\begin{tabular}{lc}
\hline Characteristics & \\
\hline Age (Year) & \\
$\mathrm{N}$ & 42 \\
Mean & 15.62 \\
$\mathrm{SD}$ & 1.87 \\
Min & 12 \\
Max & 20 \\
\hline
\end{tabular}

Table 1.2 shows the results of the age analysis of adolescents living in the Mardhatillah orphanage. A total of 42 people who live are teenagers. This category can be seen from the observation of the age of the subject, which is indicated by the minimum age value of 12 years and the maximum age of teenagers living 20 years. The average age of adolescents/subjects is 16 years.

\section{Statistics' result}

The results of research on progressive muscle relaxation on mental health were analyzed with an independent t-test, because the results of the Shapiro Wilk test showed that the data were normally distributed. The data will be presented in two tables, namely before the intervention (pre test) and after the intervention (post test) in the experimental and control groups. The results of the pre-test of adolescent mental health at the Mardhatillah Orphanage are described in the following table:

Table 1.3 Pre-Test Mental Health Test Results

\begin{tabular}{llc}
\hline & $\begin{array}{l}\text { Control } \\
\text { Group }\end{array}$ & $\begin{array}{l}\text { Experiment } \\
\text { Group }\end{array}$ \\
\hline $\mathrm{N}$ & 27 & 15 \\
mean & 23.8 & 22.2 \\
$\mathrm{SD}$ & 5.6 & 4.7 \\
signifikansi & & 0.343 \\
95 CI lower & & -1.825 \\
95 CI upper & & 5.12 \\
\hline
\end{tabular}

Based on the results, the significance value was $0.34, \mathrm{p}>0.05$, which means that there was no significant difference in the mental health of adolescents in the Mardhatillah Orphanage before the ROP assistance was carried out.

The results of the analysis of the mental health of adolescents in orphanages showed a mean result of 23.8 in the pre-control group which was included in the abnormal category. The pre-experimental group showed a mean result of 22.2 which was also included in the abnormal category. This abnormal mental health means there is a disturbance in mental health.

These disorders can be in the form of disturbances in aspects of emotional symptoms, disruptive behavior, hyperactivity - attention, problems in relationships in peer groups11. The initial state of this subject's mental health becomes interesting for progressive muscle relaxation treatment.

After the intervention in the form of progressive muscle relaxation in the experimental group, the following results were obtained:

Table 1.4 Mental Health Post Test Results

\begin{tabular}{lll}
\hline & $\begin{array}{l}\text { Control } \\
\text { Group }\end{array}$ & $\begin{array}{l}\text { Experiment } \\
\text { Group }\end{array}$ \\
\hline $\mathrm{N}$ & 27 & 15 \\
mean & 13.22 & 9.40 \\
$\mathrm{SD}$ & 8.6 & 2.69 \\
significancy & & 0.042 \\
95 CI lower & & 0.148 \\
95 CI upper & & 7.49 \\
\hline
\end{tabular}

Based on table 1.4 the results of mental health tests on adolescents at the Mardhatillah orphanage obtained a significance of 0.042 , the $p$ value $<0.05$ means that the difference in mental health between the control group and the experimental group shows a significant difference.

In the control group, the mean score of 13.22 means that the mental 
health of adolescents at the Mardhatillah Orphanage is in the normal category. In the experimental group, the mean result is 9.40 , which means that the mental health of adolescents at the Mardhatillah Orphanage is also in the normal category. There was a decrease in SDQ scores in both groups, but the decrease in the experimental group's score was greater than the control group with a difference of 3.5. This decrease was statistically significant so that the mental health of the experimental group was better than the control group.

\section{DISCUSSION}

Various forms of relaxation that can be done to reduce anxiety in the human body. Both physically and psychologically. Progressive muscle relaxation is a series of activities carried out to relax the muscles in the body, aiming to reduce anxiety in the body due to the management of alternating muscle relaxation movements ${ }^{[13]}$.

Relaxation techniques are divided into five types, namely progressive muscle relaxation, diaphragmatic breathing, imagery training, biofeedback, and hypnosis. In practice, there are similar principles between progressive muscle relaxation, imagery training, and hypnosis; i.e. the therapist uses a lot of verbal instructions to direct the client while the client concentrates on following the instructions. Someone who mastered hypnosis in general will easily do imagery training and progressive relaxation; and vice versa.

The results of the analysis showed that progressive muscle relaxation improved mental health significantly better in adolescents in the intervention group than in the control group $(\mathrm{p}=$ 0.042).

Teenagers who are in orphanages certainly have different psychological conditions from teenagers who have freer social habits. This condition also affects the mental health of $84.7 \%$ of adolescents living in orphanages such as stress, anxiety and depression. Progressive muscle relaxation was successful in reducing anxiety, stress and depression in the intervention group $(p<0.001)^{[9]}$.

The mental health of adolescents living in orphanages needs attention. Mental health which consists of various aspects, there are at least 3 top aspects that are considered, including personal integration, positive self-assessment and the ability to get along ${ }^{[10]}$. In adolescents, if the three are not balanced, it will cause mental health disorientation.

Mental health conditions that would describe teenagers in orphanages are more considered to be continuously monitored, especially during the COVID19 pandemic. It is necessary to intervene both psychosocial and relaxation approaches as mental support for adolescents living in orphanages ${ }^{[13] .}$

Progressive muscle relaxation will activate the parasympathetic nervous system by stimulating the adrenal medulla to decrease the activity of the sympathetic nervous system so that nitric oxide levels increase, lowering epinephrine, nor epinephrine, cortisol. As a result, blood pressure, pulse, and oxygen consumption decrease, so that a person feels comfortable and calm ${ }^{[15],[16]}$. The results of other studies have shown that relaxation techniques can also reduce anxiety, improve sleep [17], and reduce stress ${ }^{[18]}$.

The various literature studies above show that progressive muscle relaxation performed on adolescents living in orphanages can help improve mental health, especially during the COVID-19 pandemic.

\section{CONCLUSION}

The conclusion of this study is that progressive muscle relaxation improves the mental health of adolescents in the Mardhatillah Sukoharjo orphanage. 


ACKNOWLEDGEMENT

By the grace of Allah SWT, the Pregnancy Delivery and Child Development (RG PhD CD) research group, Faculty of Medicine, Universitas Sebelas Maret was able to complete this research on time. Thank you to LPPM UNS for providing financial assistance with contract number 260/UN27.22/HK.07.00/2021 and all board member of the Mardhatillah orphanage for granting research permits.

\section{REFERENCE}

1. Kemenkes RI. Kepmenkes Nomor HK.01.07/Menkes/413/2020 Pedoman Pencegahan dan Pengendalian Corona Virus Disease 2019 (Covid-19). Jakarta: 1-207

2. Guo F, Tian Y, Zhong F, Wu C, Cui Y, Huang C. 2020. Intensity of physical activity and depressive symptoms in college students: fitness improvement tactics in youth (fityou) project. Psycol Behav Manag. 13:797-81. https://doi.org/10.2147/PRBM.S2670

3. Meyer J, McDowell C, Lansing J, Brower C, Smith L, Tully $M$ et al. 2020. Changes in physical activity and sedentary behavior in response to covid-19 and their associations with mental health in 3052 us adult. Int J Environ Res Public Health. 17(18):6469. doi: 10.3390/ijerph17186469

4. Zhang Y, Zhang H, Ma X, Di Q. 2020. Mental health problems during the COVID-19 pandemics and the mitigation effects of exercise: A longitudinal study college students in China. Int $J$ Environ Res Public Health. 17(10):3722. doi: 10.3390/ijerph 17103722

5. Octavius GS, Silviani FR, Lesmandjaja A, Angelina, Juliansen A. 2020. Impact of covid-19 on adolescents' mental health: A systematic review. Middle
East Curr.

(27)72.

https://doi.org/10.1186/s43045-020-

00075-4

6. Jiao WY, Wang LN, Liu J, Fang SF, Jiao FY, Pettoello-Mantovani $\mathrm{M}$ et al. 2020. Behavioral and emotional disorders in children during the covid19 epidemic. J Pediatr. 221(1):264266.el. doi: 10.1016/j.jpeds.2020.03.013

7. Keliat BA, Marlianna T. 2018. BukuDKJPS-Bencana-1. Jakarta: Penerbit UI. Retrived from https://ipkji.org/wpcontent/uploads/2020/04/Buku-DKJPSBencana-1.pdf

8. Rahmah S, Asmidir A, Nurfahanah N. 2016. Masalah-masalah yang dialami anak panti asuhan dalam penyesuaian diri dengan lingkungani. Konselor 3:3(2014). 107 . https://doi.org/10.24036/020143329930-00

9. Mohammadzadeh M, Awang H, Kadir Shahar H, Ismail S. 2017. Emotional Health and Self-esteem Among Adolescents in Malaysian Orphanages. Community Ment Health J, 54(1), 117125. doi:10.1007/s10597-017-0128-5

10. Ushanandini N, Gabriel M. 2017. A study on mental health among the adolescent orphan children living in orphanages. J. humanit. soc. sci.. 7;17. ISSN 2225-0484

11. Oktaviana, M., \& Wimbarti, S. 2014. Validasi Klinik Strenghts and Difficulties Questionnaire (SDQ) sebagai Instrumen Skrining Gangguan Tingkah Laku. Jurnal Psikologi, 41(1), 101. https://doi.org/10.22146/jpsi.6961

12. Rizkiah, A., Risanty, R. D., \& Mujiastuti, R. 2020. Sistem Pendeteksi Dini Kesehatan Mental Emosional Anak Usia 4-17 Tahun Menggunakan Metode Forward Chaining. JUST IT: 
Jurnal Sistem Informasi, Teknologi Informasi Dan Komputer, 10(2), 83. https://doi.org/10.24853/justit.10.2.8393

13. Soklaridis S, Lin E, Lalani Y, Rodak T, Sockalingam S. 2020. Mental health interventions and supports during COVID- 19 and other medical pandemics: A rapid systematic review of the evidence. Gen. Hosp. Psychiatry. 66;133-146. doi:10.1016/j.genhosppsych.2020.08.0 07

14. Livina PH. 2018. Relaksasi otot untuk menurunkan stress. Retrived From http://digilib.unimus.ac.id/files/disk1/1 66/jtptunimus-gdl-artantiema-8274-39.babii.pdf

15. Patimah, I. 2020. Konsep relaksasi zikir dan implikasinya terhadap penderita gagal ginjal kronis (M. B. Muvid (ed.)). Adanu Abimata.

16. Torales, J., O’Higgins, M., Barrios, I., González, I., \& Almirón, M. (2020). An overview of jacobson's progressive muscle relaxation in managing anxiety. Revista Argentina de Clinica Psicologica, 29(3), 17-23. https://doi.org/10.24205/03276716.202 0.748

17. Liu, K., Chen, Y., Wu, D., Lin, R., Wang, Z., \& Pan, L. 2020. Effects of progressive muscle relaxation on anxiety and sleep quality in patients with COVID-19. Complementary Therapies in Clinical Practice, 39, 101132. https://doi.org/10.1016/j.ctcp.2020.101 132

18. Wilczyńska, D., Łysak-Radomska, A., Podczarska-Głowacka, M., Zajt, J., Dornowski, M., \& Skonieczny, P. 2019. Evaluation of the effectiveness of relaxation in lowering the level of anxiety in young adults - A pilot study.
International Journal of Occupational Medicine and Environmental Health, 32(6), 817-824. https://doi.org/10.13075/ijomeh.1896.0 1457 